\title{
Interactions of iron-thiol-nitrosyl compounds with the phosphoroclastic system of Clostridium sporogenes
}

\author{
Martin J. Payne, ${ }^{1 *}$ Christopher Glidewell ${ }^{2}$ and Richard Cammack ${ }^{1}$ \\ ${ }^{1}$ Division of Biomolecular Sciences, King's College London, Campden Hill Road, London W8 7AH, UK \\ ${ }^{2}$ Chemistry Department, University of St Andrews, Fife KY16 9ST, UK
}

(Received 25 April 1990; accepted 13 June 1990)

\begin{abstract}
Certain reagents, such as ascorbate or iron salts and thiols, enhance the bacteriostatic action of nitrite on foodspoilage bacteria. This may be due to the formation of nitric oxide and iron-thiol-nitrosyl ([Fe-S-NO|) complexes. The minimum concentrations of these reagents required to inhibit growth of Clostridium sporogenes were investigated. A mixture of nitrite $(0.72 \mathrm{mM})$ with iron $(1.44 \mathrm{mM})$ and cysteine $(2.16 \mathrm{mM})$ was found to be extremely inhibitory when autoclaved and diluted into the culture medium. This mixture caused rapid cessation of growth and loss of cell viability at a final concentration corresponding to $40 \mu \mathrm{M}$-nitrite. If added to the initial culture medium, it prevented growth at $5 \mu \mathrm{M}$-nitrite. The mixture was more inhibitory, on the basis of the nitrite concentration used, than the 'Perigo factor', obtained by autoclaving nitrite in growth medium. [Fe-S-NO] compounds of known chemical structure were tested to determine if they were responsible for this effect. Total inhibition of cell growth was observed with the tetranuclear clusters $\left[\mathrm{Fe}_{4} \mathrm{~S}_{3}(\mathrm{NO})_{7}\right]$ (Roussin's black salt), $\left[\mathrm{Fe}_{4} \mathrm{~S}_{4}(\mathrm{NO})_{4}\right]$ or $\left[\mathrm{Fe}_{4} \mathrm{Se}_{3}(\mathrm{NO})_{7}\right]$, added at concentrations equivalent to $10 \mu \mathrm{M}$-nitrite, or with $\left[\mathrm{Fe}_{2}(\mathrm{SMe})_{2}(\mathrm{NO})_{4}\right]$ (methyl ester of Roussin's red salt), equivalent to $200 \mu \mathrm{M}$-nitrite. The rate of hydrogen production in growing cell cultures was inhibited by $\left[\mathrm{Fe}_{4} \mathrm{~S}_{3}(\mathrm{NO})_{7}\right]$ at levels equivalent to $2.5 \mu \mathrm{M}$-nitrite. EPR spectra of the inhibited cells showed features with $\boldsymbol{g}$-values of $\mathbf{2 . 0 3}$, characteristic of mononuclear iron-nitrosyl species, and, under nonreducing conditions, an unusual signal at $g=1 \cdot 65$. There was no correlation between growth inhibition and the $g=2.03$ signal, though there was a better correlation between inhibition and the $g=1.65$ signal. The direct effects of the compounds were tested on the iron-sulphur proteins of the phosphoroclastic system, namely ferredoxin, pyruvate-ferredoxin oxidoreductase and hydrogenase. EPR spectra and enzyme assays showed that these proteins were not destroyed by $\left.\mid \mathrm{Fe}_{4} \mathrm{~S}_{3}(\mathrm{NO})_{7}\right],\left|\mathrm{Fe}_{4} \mathrm{~S}_{4}(\mathrm{NO})_{4}\right|,\left[\mathrm{Fe}_{2}(\mathrm{SMe})_{2}(\mathrm{NO})_{4}\right],\left[\mathrm{Fe}(\mathrm{SPh})_{2}(\mathrm{NO})_{2}\right]$, or $\mathrm{M2}$ (an autoclaved mixture of $66 \mathrm{mM}$-cysteine, $3.6 \mathrm{mM}-\mathrm{FeSO}_{4}$ and $0.72 \mathrm{mM}-\mathrm{NaNO}_{2}$ ) at concentrations higher than those that caused total inhibition of cell growth. Inhibition of cells by $[\mathrm{Fe}-\mathrm{S}-\mathrm{NO}]$ compounds is unlikely to be due to interaction with the preformed enzymes. The possible formation of iron-nitrosyl complexes in vivo, and their inhibitory actions, are discussed.
\end{abstract}

\section{Introduction}

Nitrite is widely used as an antimicrobial agent, particularly in meats. A number of studies on the inhibition of clostridial growth by heated mixtures of nitrite with iron and thiol-containing compounds have been carried out over the last 15 years (Incze et al., 1974; Riha \& Solberg, 1975; Huhtanen \& Wasserman, 1975;

\footnotetext{
Abbreviations: [Fe-S-NO], iron-thiol-nitrosyl; M1, 66 mM-cysteine $+3.6 \mathrm{mM}_{-} \mathrm{FeSO}_{4}+0.72 \mathrm{mM}-\mathrm{NaNO}_{2} ; \mathrm{M} 2$, as $\mathrm{M} 1$, but autoclaved at $121^{\circ} \mathrm{C}$ for $15 \mathrm{~min}$; $\mathrm{M} 3$, autoclaved mixture of $2.16 \mathrm{~mm}$-cysteine + $0.72 \mathrm{~mm}-\mathrm{NaNO}_{2}+1.44 \mathrm{mM}^{-\mathrm{FeSO}_{4}}$.
}

Asan \& Solberg, 1976). Huhtanen \& Wassserman (1975) suggested that Roussin's black salt, $\left[\mathrm{Fe}_{4} \mathrm{~S}_{3}(\mathrm{NO})_{7}\right]$ (Fig. $1 c$ ), was the 'Perigo inhibitor'; an inhibitor (not yet isolated) of clostridial growth discovered by Perigo et al. (1967) after heating nitrite in clostridial fluid growthmedium.

Studies carried out under a range of growth conditions have shown that the inhibitory effect of nitrite on clostridial growth in liquid culture is enhanced by adding $\mathrm{Fe}(\mathrm{II})$ or $\mathrm{Fe}(\mathrm{III})$ salts and thiol-containing compounds (Huhtanen \& Wasserman, 1975; Moran et al., 1975; Asan \& Solberg, 1976). Typical final concentrations necessary to inhibit clostridial growth were $0.1-0.2 \mathrm{~mm}-\mathrm{Fe}(\mathrm{II}), 0.04-0.29 \mathrm{~mm}-$ nitrite, and 1-10 mM- 
cysteine. Some inhibitory nitrite derivatives do not require heat in their synthesis and cannot strictly be classed as Perigo factors. Huhtanen \& Wasserman (1975) found that the effect of iron was more pronounced when nitrite was added to medium which had already been autoclaved with iron salts present, rather than if both nitrite and iron salts were added prior to autoclaving.

Van Roon (1974) suggested that an [Fe-S-NO] complex may be responsible for inhibition of clostridial growth in cooked meat products. A number of such complexes have since been synthesized chemically; they are effective nitrosating agents, which may account for some of their inhibitory actions (Butler et al., 1988).

[Fe-S-NO] complexes are numerous and chemically reactive. Their formation and interconversions have recently been reviewed by Butler et al. (1988). $\left[\mathrm{Fe}_{4} \mathrm{~S}_{3}(\mathrm{NO})_{7}\right]$ readily decomposes to form the paramagnetic mono-iron-nitrosyl species $\left[\mathrm{Fe}(\mathrm{NO})_{2}(\mathrm{SR})_{2}\right]$. Under alkaline conditions, these can recombine to form Roussin's red salt, $\left[\mathrm{Fe}_{2}(\mathrm{SH})_{2}(\mathrm{NO})_{4}\right]$. Both black and red salts have antimicrobial activity. The methyl ester of the red salt, $\left[\mathrm{Fe}_{2}(\mathrm{SMe})_{2}(\mathrm{NO})_{4}\right]$ (Fig. $1 b$ ) has been isolated from natural vegetable sources, and is a known mutagen and tumour promoter. It can be formed by incubating nitrite with parsley (Petroselinium crispum), which contains the iron-sulphur protein ferredoxin (Baty et al., 1987; Butler et al., 1985a). The ester can also be readily synthesized in vitro (Butler et al, 1985b), and may cause oesophagal cancer (Butler et al., 1985a). The decomposed ester is a much more potent nitrosation agent than the pure complex. In addition, paramagnetic $\left[\mathrm{Fe}(\mathrm{NO})_{2}(\mathrm{SH})_{2}\right]$ species are formed by reaction of nitrite with preformed iron-sulphur clusters (Butler et al., 1988), such as those present in clostridial [4Fe-4S] 'ferredoxin-type' proteins, which occur widely in electron-transfer pathways.

Mononuclear iron-nitrosyl species of the type $\left[\mathrm{Fe}(\mathrm{NO})_{2}(\mathrm{SR})_{2}\right]^{-}$are distinctive in that they have readily-detected EPR spectra, centred around $g=2.03$. By this means, it has been shown that they are readily formed from nitrite, both in vitro and in vivo. For example, Reddy et al. (1983) detected the formation of mononuclear iron-nitrosyl complexes by EPR spectroscopy after adding $\mathrm{NaNO}_{2}$ to sonicated cells of C. botulinum. Addition of ascorbate with the nitrite to cell extracts resulted in an increase in EPR signal intensity. It was hypothesized that iron-sulphur proteins might be the most important site of nitrite reaction, and that the resultant iron-nitrosyl formation was the basis of the antibotulinal activity of nitrite in foods.

However, in our recent studies of the effects of mixtures of iron, nitrite and thiols on the growth of vegetative cells and hydrogen production by the model food-spoilage bacterium Clostridium sporogenes (Payne et

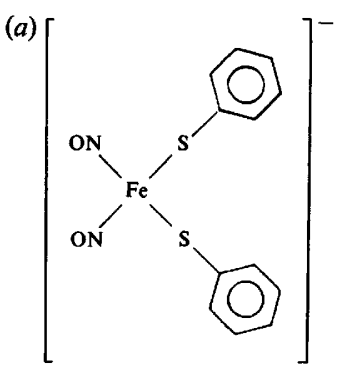<smiles>CS1([N+](=O)[O-])S[PH]1([N+](=O)[O-])[N+](=O)[O-]</smiles>
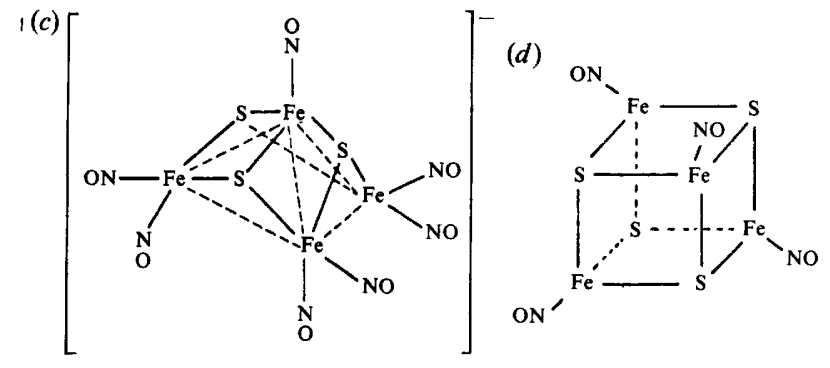

Fig. 1. Structures of [Fe-S-NO] complexes which act as bacteriostatic agents. $(a)\left[\mathrm{Fe}(\mathrm{SPh})_{2}(\mathrm{NO})_{2}\right]$ - Mono-iron-nitrosyl complex; (b) $\left[\mathrm{Fe}_{2}(\mathrm{SMe})_{2}(\mathrm{NO})_{4}\right]$ - the methyl ester of Roussin's red salt; (c) $\left[\mathrm{Fe}_{4} \mathrm{~S}_{3}(\mathrm{NO})_{7}\right]$ - Roussin's black salt; (d) $\left[\mathrm{Fe}_{4} \mathrm{~S}_{4}(\mathrm{NO})_{4}\right]$. The monoiron complex $\left[\mathrm{Fe}_{2}(\mathrm{SPh})_{2}(\mathrm{NO})_{2}\right]$ is paramagnetic and gives large EPR signals at $g=2 \cdot 03$. The others are diamagnetic, and therefore EPRsilent.

al., 1990), we found no correlation between inhibition and the formation of the $g=2.03$ signals. These studies also showed that the most inhibitory mixtures were obtained by autoclaving nitrite with iron and cysteine before adding to the culture medium, and were EPRsilent. These were more effective at inhibiting cell growth than either nitric oxide or the 'Perigo inhibitor' obtained by autoclaving the growth medium with nitrite (Perigo et al., 1967).

Although the mononuclear iron-nitrosyl species appear not to be implicated in the inhibition of clostridial growth, other complexes are more effective. Moran et al. (1975) found that germination of C. sporogenes spores was inhibited by $\left[\mathrm{Fe}_{4} \mathrm{~S}_{3}(\mathrm{NO})_{7}\right]$ at a concentration of $50 \mu \mathrm{M}$, but not at $12.5 \mu \mathrm{M}$ or less. They concluded that the inhibition of growth by nitrite autoclaved in medium could be due to a combination of $\left[\mathrm{Fe}_{4} \mathrm{~S}_{3}(\mathrm{NO})_{7}\right],\left[\mathrm{Fe}(\mathrm{NO})_{2}(\mathrm{Cys})_{2}\right]$ and $S$-nitrosocysteine, although no single compound was detected at a level adequate for inhibition. [ $\left.\mathrm{Fe}(\mathrm{NO})_{2}(\mathrm{Cys})_{2}\right]$ also inhibited the growth of Staphylococcus saprophyticus (Larkworthy et al., 1977).

Doyle et al. (1980) showed that direct transfer of coordinated nitrosyl groups from metal nitrosyls to metalloproteins could occur without the intervention of unassociated nitric oxide. So far, the interaction of 
[Fe-S-NO] complexes with iron-sulphur proteins, such as those occurring in clostridia, has not been extensively investigated.

In the present study, we investigated the effects of adding preformed [Fe-S-NO] complexes (Fig. 1) to growing cultures of $C$. sporogenes. We also monitored the effect of adding the [Fe-S-NO] species directly, in vitro, to cell extracts containing the iron-sulphur enzymes of the phosphoroclastic system, namely pyruvateferredoxin oxidoreductase, ferredoxin and hydrogenase. In this way, the concentrations necessary for inhibition of cell growth were compared to those necessary to inhibit enzyme activity.

\section{Methods}

Preparation of inhibitors. A filter-sterilized solution of $66 \mathrm{mM}$ cysteine, $3.6 \mathrm{mM}^{-\mathrm{FeSO}_{4}}$ and $0.72 \mathrm{mM}-\mathrm{NaNO}_{2}$ (denoted $\mathrm{M} 1$ ) was added at $56 \mathrm{ml} \mathrm{l}^{-1}$ concentration to Oxoid nutrient broth no. 2 (autoclaved separately), prior to the addition of glucose and thioglycollate. Mixture M2 was similar, but was autoclaved before adding to the medium. M1 or M2 were added to normal cultures after $4 \mathrm{~h}$ growth, by which time the cells had reached exponential-phase.

Roussin's Black Salt, $\left[\mathrm{Fe}_{4} \mathrm{~S}_{3}(\mathrm{NO})_{7}\right]$. The method of synthesis was modified from Roussin (1858). Sodium nitrite $(8 \mathrm{~g})$ was dissolved in $40 \mathrm{ml}$ of water. This was added to a $42 \mathrm{ml}$ solution of $17 \%(\mathrm{v} / \mathrm{v})$ ammonium polysulphide (BDH). The mixture was added then heated to boiling. Immediately after boiling point was reached, $160 \mathrm{ml}$ of $0.45 \mathrm{M}^{-} \mathrm{FeSO}_{4}$ was added. The black precipitate formed was boiled vigorously for $15 \mathrm{~min}$, while $22 \%$ ammonia solution was added at regular time intervals, until a total volume of $25 \mathrm{ml}$ had been added. The precipitate was then quickly filtered while very hot. The salt was purified from the filtrate by extracting twice with diethyl ether. Dry crystals of the salt were obtained by flushing the solution with oxygenfree nitrogen, and were stored under nitrogen, to prevent oxidation, at $-20^{\circ} \mathrm{C}$.

Preparation of $\left[\mathrm{Fe}_{4} \mathrm{~S}_{4}(\mathrm{NO})_{4}\right], \mathrm{Na}^{+}\left[\mathrm{Fe}_{4} \mathrm{Se}_{3}(\mathrm{NO})_{7}\right]^{-}(0.3 \mathrm{~g})$ and eletal sulphur $(0.5 \mathrm{~g})$ were heated under reflux in dry toluene $(50 \mathrm{ml})$, under nitrogen for $16 \mathrm{~h}$. After cooling, the mixture was filtered through a packed bed of Hyflo-supercel ( $2 \mathrm{~cm}$ deep), and the solvent was removed (oil pump vacuum) from the filtrate. The residue was dissolved in the minimum volume of chloroform and chromatographed on a silica column $(6 \mathrm{~cm} \times 1 \mathrm{~cm})$; the black band was eluted with chloroform. Removal of the solvent gave $\left.\mathrm{Fe}_{4} \mathrm{~S}_{4}(\mathrm{NO})_{4}\right]$ as black shiny plates $(70 \%$ yield)

Other $[\mathrm{Fe}-\mathrm{S}-\mathrm{NO}]$ complexes. Previously described methods were used for the preparation of $\left[\mathrm{Fe}_{2}(\mathrm{SMe})_{2}(\mathrm{NO})_{4}\right], \mathrm{Na}^{+}\left[\mathrm{Fe}_{4} \mathrm{Se}_{3}(\mathrm{NO})_{7}\right]^{-}$ (Butler et al., 1983), $\mathrm{Et}_{4} \mathrm{~N}^{+}\left[\mathrm{Fe}(\mathrm{NO})_{2}(\mathrm{SPh})_{2}\right]^{-}$(Strasdeit et al., 1986) and $N$-acetyl-S-nitrosopenicillamine (Field et al., 1978).

Inhibition of cell growth by $[\mathrm{Fe}-\mathrm{S}-\mathrm{NO}]$ complexes. Cultures of C. sporogenes NCIB 10696 were grown in Oxoid nutrient broth as described in the accompanying paper (Payne et al., 1990). After the cells had reached exponential-phase growth (approximately $4 \mathrm{~h}$ ), an [Fe-S-NO] salt (dissolved in ethanol) or M2 was aseptically added, to give final concentrations ranging from 3.3 to $200 \mu \mathrm{M}$. Of the $\mathrm{Fe}-\mathrm{S}-\mathrm{NO}$ salts used, only $\left[\mathrm{Fe}_{4} \mathrm{~S}_{3}(\mathrm{NO})_{7}\right]$ and $\left[\mathrm{Fe}_{4} \mathrm{Se}_{3}(\mathrm{NO})_{7}\right]$ were completely soluble in the growth medium. $\left[\mathrm{Fe}_{2}(\mathrm{SPh})_{2}(\mathrm{NO})_{2}\right]$ and $\left[\mathrm{Fe}_{4} \mathrm{~S}_{4}(\mathrm{NO})_{4}\right]$ formed a fine blackish precipitate, while $\left[\mathrm{Fe}_{2}(\mathrm{SMe})_{2}(\mathrm{NO})_{4}\right]$ formed a more dense orange precipitate. Cells were harvested after a further $12 \mathrm{~h}$, by centrifugation at $16300 \mathrm{~g}$ for $10 \mathrm{~min}$ at $4^{\circ} \mathrm{C}$. Viability of inhibited cells was tested by re-inoculating into fresh growth medium.

Measurement of hydrogen production during cell growth. Cultures $(5 \mathrm{ml})$ were incubated at $37^{\circ} \mathrm{C}$ in $27 \mathrm{ml}$ glass vials, sealed with redrubber septa. Hydrogen evolved during growth was measured at regular time intervals by withdrawing $100 \mu \mathrm{l}$ aliquots of gas from above each culture and injecting into a gas chromatograph. After several hours of cell growth, a solution of the inhibitor was added.

The preparations of ferredoxin, soluble cell-free extracts and hydrogenase were as described in the accompanying paper (Payne $e t$ al., 1990). Assays of pyruvate-ferredoxin oxidoreductase and hydrogenase activity were based on the rate of reduction of methyl viologen (Payne et al., 1990). The preparation of samples for EPR spectroscopy was as described in the accompanying paper (Payne et al., 1990).

\section{Results}

\section{Inhibition of cell growth}

Prevention of cell growth by inhibitors in the medium. Mixtures of $\mathrm{NaNO}_{2}, \mathrm{FeSO}_{4}$ and cysteine inhibited growth when added to growing cultures of $C$. sporogenes cells (Fig. 2). These were more inhibitory if they were autoclaved prior to adding to growth medium which contained no cells, the threshold final concentrations necessary to prevent the initiation of cell growth being $5.0,2.5$ and $15.0 \mu \mathrm{M}$ respectively. However, when the

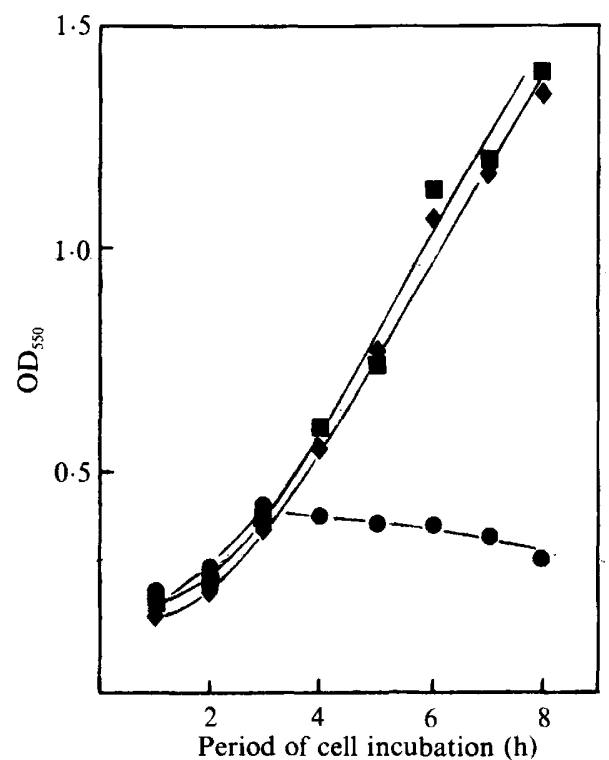

Fig. 2. Inhibition of exponential-phase growth of $C$. sporogenes by MI and $M 2$. Cultures of $C$. sporogenes were inoculated into liquid growth medium and incubated at $37^{\circ} \mathrm{C}$. Turbidity measurements were made each hour over an $8 \mathrm{~h}$ period. After $3 \mathrm{~h}$ of growth, inhibitor M1 or M2 was added, at a final concentration of $56 \mathrm{ml} \mathrm{l}^{-1}$. Each culture was prepared in triplicate. $\mathbf{\square}$, Control culture; $\bullet$, culture + M1 ; ๑, culture + M2. 
same autoclaved mixture was added to medium in which cells had reached exponential-phase growth, then growth continued, and cell yields (expressed as wet weight of cells per litre of growth medium) were around $20 \%$ of control cell yields (Table 1). When these cells were inoculated into normal growth medium, cell growth recovered fully.

Effect of unheated mixture M1. The minimum concentration of iron, nitrite and cysteine necessary to cause total growth inhibition was investigated (Table 1). For purposes of comparability, these were added at concentrations similar to those used by Moran et al. (1975). A stock solution of $3.6 \mathrm{~mm}-\mathrm{FeSO}_{4}, 0.72 \mathrm{mM}-\mathrm{NaNO}_{2}$ and 66 mM-cysteine (denoted M1) was prepared. This was clear, odourless and colourless at first, but darkened, over a period of hours, to a deep yellow colour. If the solution was prepared anaerobically, it remained colourless. Cell yield of $C$. sporogenes (expressed as wet weight of cells per litre of growth medium) was not significantly affected (Table 1) by growth with M1, added at a final concentration of $40 \mu \mathrm{M}-\mathrm{NaNO}_{2}$. However, cells were dark in colour, clumped together and had a similar consistency to cell pellets after growth with $4 \mathrm{~mm}$-nitrite.

Effect of heated mixtures. If M1 was added to the total volume of growth medium, at a final concentration of $40 \mu \mathrm{M}-\mathrm{NaNO}_{2}$, and then autoclaved, it caused total inhibition of growth of an inoculum of $C$. sporogenes cells. However, after re-inoculation of these cultures into fresh growth medium, the cells remained viable.

When M1 was autoclaved, a dark brown solution (M2) was formed. The effects of the autoclaved mixture M2; at the same concentration, were much more marked. It caused cell lysis (observed as a decrease in optical density) and total inhibition of growth (Fig. 2). The wet weight of clostridia inoculated into 101 of medium was around $0.3 \mathrm{~g}$, but after adding M2, only $0.1 \mathrm{~g}$ of cells were eventually harvested following a further $16 \mathrm{~h}$ growth. Cell pellets were black, and readily dispersed in buffer, producing a flaky suspension. They were not viable if reinoculated into fresh medium (Table 1). When the nitrite concentration in M2 was decreased from $720 \mu \mathrm{M}$ to $100 \mu \mathrm{M}$ (giving a final concentration of nitrite in growth medium of $5.6 \mu \mathrm{M}), 90 \%$ inhibition of growth occurred. Therefore $\mathrm{Fe}^{2+}$ ions, $\mathrm{NaNO}_{2}$ and cysteine appeared to produce a more effective inhibitor of cell growth when autoclaved first, as a concentrated solution (M2), than if diluted into the medium and then autoclaved. In each case inhibition was dependent on all three reagents. If nitrite, cysteine or $\mathrm{Fe}^{2+}$ was omitted, the mixture failed to inhibit growth (results not shown).

Optimization of the concentrations of iron, nitrite and cysteine. The antimicrobial action of nitrite was not dependent on the presence of a large excess of reducing
Table 1. Inhibition of exponential-phase cultures of C. sporogenes by mixtures of $\mathrm{NaNO}_{2}, \mathrm{FeSO}_{4}$ and cysteine

Cell yield as \% of control was calculated from values of wet weights of harvested cells after growth in the presence or absence of inhibitors, and cultures were grown in triplicate. A, mixture autoclaved after adding to growth medium; B, mixture autoclaved and added to separately autoclaved growth medium. Cells were incubated in the growth medium for $4 \mathrm{~h}$ at $37^{\circ} \mathrm{C}$ prior to adding $\mathrm{B}$.

\begin{tabular}{ccccccc}
\hline \hline \multicolumn{2}{c}{ Concns of inhibitors $(\mu \mathrm{M})$} & & Heat & $\begin{array}{c}\text { Cell yield } \\
(\% \text { of control) })\end{array}$ & $\begin{array}{c}\text { Growth } \\
\text { in fresh } \\
\text { medium }\end{array}$ \\
\cline { 1 - 3 } $\mathrm{NaNO}_{2}$ & $\mathrm{FeSO}_{4}$ & Cysteine & treatment & none & 98 & yes \\
\hline 40 & 200 & 3700 & n & $<3$ & yes \\
40 & 200 & 3700 & A & $<3$ & no \\
40 & 200 & 3700 & B & $<3$ & no \\
40 & 80 & 120 & B & 10 & yes \\
5.6 & 200 & 3700 & B & $20^{*}$ & yes \\
5.0 & 2.5 & 15 & B & \\
\hline \hline
\end{tabular}

* Inhibitor caused total inhibition if added to growth medium prior to inoculation with cells.

agent, because the cysteine concentration could be decreased from $66 \mathrm{mM}$ to $2.16 \mathrm{mM}$ (121 $\mu \mathrm{M}$ final concentration). When the proportion of cysteine was lowered further, the autoclaved solution (prior to addition to growth medium) formed a rust-coloured sediment, indicating oxidation of $\mathrm{Fe}^{2+}$ ions to $\mathrm{Fe}^{3+}$ by oxygen. Cells grew normally in medium containing this oxidized mixture. Optimal concentrations were found to be $2.16 \mathrm{~mm}$-cysteine, $0.72 \mathrm{mM}-\mathrm{NaNO}_{2}$, and $1.44 \mathrm{mM}-\mathrm{FeSO}_{4}$ This mixture was denoted as M3. If M3 was prepared under aerobic conditions, it had a pH of 4.8 after autoclaving, but if prepared anaerobically, it had a $\mathrm{pH}$ of 6.8. Cell growth was totally inhibited by either preparation when diluted into medium to give final $\mathrm{NaNO}_{2}$, $\mathrm{FeSO}_{4}$ and cysteine concentrations of 40,80 and $121 \mu \mathrm{M}$ respectively. Cells showed no signs of recovery after inoculation into normal growth medium.

Effects of preformed $[\mathrm{Fe}-\mathrm{S}-\mathrm{NO}]$ complexes. $\left[\mathrm{Fe}_{4}(\mathrm{Se})_{3}(\mathrm{NO})_{7}\right],\left[\mathrm{Fe}_{4} \mathrm{~S}_{3}(\mathrm{NO})_{7}\right]$ and $\left[\mathrm{Fe}_{4} \mathrm{~S}_{4}(\mathrm{NO})_{4}\right]$ totally inhibited cell growth when added at $10 \mu \mathrm{M}$ concentration (Table 2). $\left[\mathrm{Fe}_{2}(\mathrm{SMe})_{2}(\mathrm{NO})_{4}\right]$ was inhibitory at $200 \mu \mathrm{M}$ concentration. M2 also caused total growth inhibition when nitrite was present at a final concentration of $40 \mu \mathrm{M}$. The nitrosamine $S$-nitroso-DL-penicillamine, at similar concentrations, did not inhibit cell growth.

\section{Inhibition of the enzymes of the phosphoroclastic system}

After the addition of mixture M1, with nitrite present at a maximal final concentration of $40 \mu \mathrm{M}$, to cultures of C. sporogenes, hydrogen production was decreased to $33 \%$ of the rate in control cultures within $2 \mathrm{~h}$ (Fig. 3). 


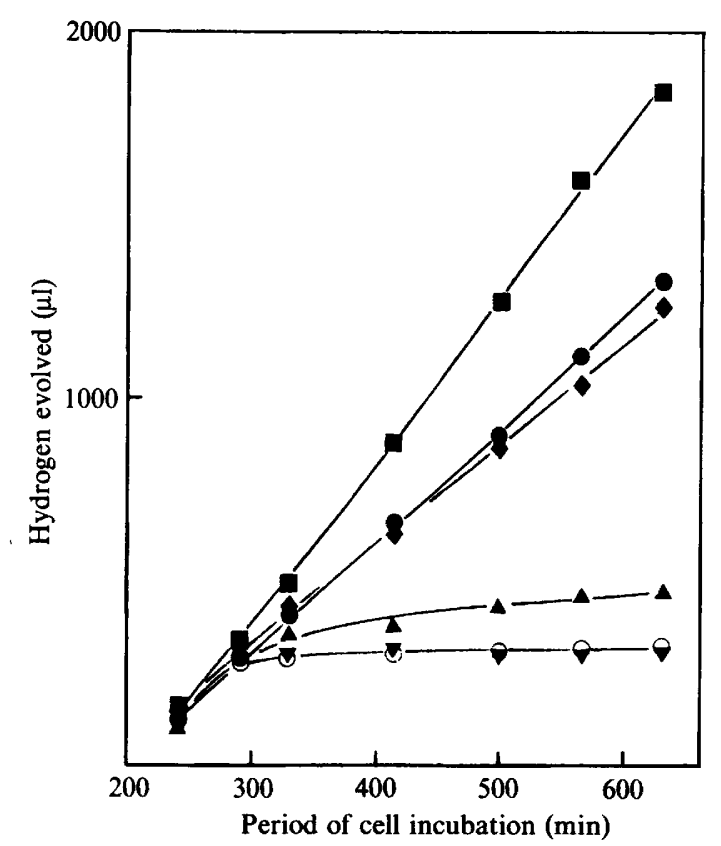

Fig. 3. Inhibition of hydrogen production with time, in growing cultures of $C$. sporogenes after treatment with $\left[\mathrm{Fe}_{4} \mathrm{~S}_{3}(\mathrm{NO})_{7}\right]$, M1 or $\mathrm{M} 2$. Cultures were grown into exponential-phase under normal growth conditions at $37^{\circ} \mathrm{C}$. After $330 \mathrm{~min}$ of growth, inhibitors were added. Hydrogen production was monitored throughout growth, at regular time intervals. $\mathrm{E}$, Cultures with water added; $\mathrm{O}, 175 \mu \mathrm{M}\left[\mathrm{Fe}_{4} \mathrm{~S}_{3}(\mathrm{NO})_{7}\right]$ added; $\Delta, 17.5 \mu \mathrm{M}\left[\mathrm{Fe}_{4} \mathrm{~S}_{3}(\mathrm{NO})_{7}\right]$ added; $\bullet, 1.75 \mu \mathrm{M}\left[\mathrm{Fe}_{4} \mathrm{~S}_{3}(\mathrm{NO})_{7}\right]$ added; $\nabla, \mathrm{M} 2$ added at $56 \mathrm{ml} \mathrm{l}^{-1} ; \diamond, \mathrm{M} 2$ added at $5.6 \mathrm{ml} \mathrm{l}^{-1}$.

This concentration is insufficient to prevent cell growth (Payne et al., 1990). With the bacteriostatic autoclaved mixture M2, hydrogen production was completely inhibited within $40 \mathrm{~min}$. [ $\left[\mathrm{Fe}_{4} \mathrm{~S}_{3}(\mathrm{NO})_{7}\right](17.5 \mu \mathrm{M})$ inhibited hydrogen production over a period of $330 \mathrm{~min}$.

Soluble extracts from cells grown with the various inhibitors were tested for hydrogenase and pyruvateferredoxin reductase activities. Extracts from cells grown with $56 \mathrm{ml} \mathrm{l}^{-1}$ of the unheated mixture M1, a concentration which permitted normal growth, had $13 \%$ and $21 \%$ of control specific activities for hydrogenase and pyruvate-ferredoxin oxidoreductase respectively. Extracts from cells grown with $56 \mathrm{ml}^{-1}$ of the heated mixture M2 had no pyruvate-ferredoxin oxidoreductase or hydrogenase activity. However, the cells in this case were non-viable and the loss of enzyme activity could have been a secondary consequence of cell death.

The sensitivity of the enzymes in vitro to the inhibitory iron-nitrosyl complexes was tested by treating soluble extracts from normal cells with the mixtures and estimating their enzyme activities. After a $5 \mathrm{~min}$ incubation of crude extract with M1 or M2 (at concentrations inhibitory to growth) at room temperature, pyruvate-ferredoxin oxidoreductase and hydrogen-
Table 2. Minimum concentrations of $[\mathrm{Fe}-\mathrm{S}-\mathrm{NO}]$ species inhibiting clostridial growth

Cultures were incubated at $37^{\circ} \mathrm{C}$ in normal growth medium for $4 \mathrm{~h}$ prior to the aseptic addition of each inhibitor. After a further $12 \mathrm{~h}$ each culture was inoculated into fresh growth medium devoid of inhibitor, and incubated overnight at $37^{\circ} \mathrm{C}$.

\begin{tabular}{lcc}
\hline \multicolumn{1}{c}{ [Fe-S-NO] complex } & $\begin{array}{c}\text { Concn } \\
\text { inhibitory to } \\
\text { growth }(\mu \mathrm{M})\end{array}$ & $\begin{array}{c}\text { Growth } \\
\text { in fresh } \\
\text { medium }\end{array}$ \\
\hline$\left[\mathrm{Fe}(\mathrm{SPh})_{2}(\mathrm{NO})_{2}\right]$ & $>10$ & yes \\
{$\left[\mathrm{Fe}_{2}(\mathrm{SMe})_{2}(\mathrm{NO})_{4}\right]$} & 200 & yes \\
{$\left[\mathrm{Fe}_{4} \mathrm{~S}_{3}(\mathrm{NO})_{7}\right]$} & 10 & no \\
& $3 \cdot 3$ & yes \\
{$\left[\mathrm{Fe}_{4} \mathrm{Se}_{3}(\mathrm{NO})_{7}\right]$} & 10 & no \\
& $3 \cdot 3$ & yes \\
{$\left[\mathrm{Fe}_{4} \mathrm{~S}_{4}(\mathrm{NO})_{4}\right]$} & 10 & no \\
$\mathrm{M}_{2}$ & $3 \cdot 3$ & yes \\
& $\left(40 \mu \mathrm{M}-\mathrm{NaNO}_{2}\right)$ & no \\
$S$-Nitroso-DL-penicillamine & $\left(10 \mu \mathrm{M}-\mathrm{NaNO}_{2}\right)$ & yes \\
\hline \hline
\end{tabular}

Table 3. Effect of $[\mathrm{Fe}-\mathrm{S}-\mathrm{NO}]$ salts on the activity of pyruvate-ferredoxin oxidoreductase $(P F R)$ and hydrogenase

Partially purified extract devoid of ferredoxin $(18 \mathrm{mg}$ protein $\mathrm{ml}^{-1}$ ) was incubated with each salt at $30^{\circ} \mathrm{C}$ for $15 \mathrm{~min}$ under argon, prior to assaying for pyruvate-ferredoxin oxidoreductase and hydrogenase activity. All assays were performed at room temperature. Specific activities are means of three determinations, \pm SD.

\begin{tabular}{|c|c|c|}
\hline $\begin{array}{l}{[\mathrm{Fe}-\mathrm{S}-\mathrm{NO}] \text { complex }} \\
\qquad(1.3 \mathrm{mM})\end{array}$ & $\begin{array}{l}10^{3} \times \text { Specific activity of } \\
\text { PFR }\left(\mathrm{Ug}^{-1}\right)\end{array}$ & $\begin{array}{l}\text { Percentage of } \\
\text { control activity }\end{array}$ \\
\hline $\begin{array}{l}\mathrm{No} \text { inhibitor added } \\
{\left[\mathrm{Fe}(\mathrm{SPh})_{2}(\mathrm{NO})_{2}\right]} \\
{\left[\mathrm{Fe}_{2}(\mathrm{SMe})_{2}(\mathrm{NO})_{4}\right]} \\
{\left[\mathrm{Fe}_{4} \mathrm{~S}_{4}(\mathrm{NO})_{4}\right]} \\
{\left[\mathrm{Fe}_{4} \mathrm{Se}_{3}(\mathrm{NO})_{7}\right]} \\
{\left[\mathrm{Fe}_{4} \mathrm{~S}_{3}(\mathrm{NO})_{7}\right]} \\
{\left[\mathrm{Fe}_{4} \mathrm{~S}_{3}(\mathrm{NO})_{7}\right](6 \cdot 2 \mathrm{mM})}\end{array}$ & $\begin{array}{l}299 \pm 38 \\
263 \pm 17 \\
248 \pm 24 \\
268 \pm 7 \\
302 \pm 14 \\
260 \pm 28 \\
86 \pm 17\end{array}$ & $\begin{array}{r}100 \\
88 \\
83 \\
90 \\
100 \\
87 \\
29\end{array}$ \\
\hline \multicolumn{3}{|c|}{$\begin{array}{c}\text { Specific activity of hydrogenase } \\
1000 \times \mathrm{Ug}^{-1} \pm \mathrm{SD} \text { (3) }\end{array}$} \\
\hline $\begin{array}{l}\text { No inhibitor added } \\
{\left[\mathrm{Fe}_{4} \mathrm{~S}_{3}(\mathrm{NO})_{7}\right](1.3 \mathrm{mM})} \\
{\left[\mathrm{Fe}_{4} \mathrm{~S}_{3}(\mathrm{NO})_{7}\right](6.2 \mathrm{mM})}\end{array}$ & $\begin{array}{l}8.6 \pm 1.6 \\
5.7 \pm 0.8 \\
0.3 \pm 0.2\end{array}$ & $\begin{array}{r}100 \\
66 \\
3\end{array}$ \\
\hline
\end{tabular}

ase activities were not significantly inhibited, although a $23 \%$ decrease in activity of hydrogenase was observed after incubation with $\mathrm{M} 1$ for $15 \mathrm{~min}$. A whole range of [Fe-S-NO] salts was tested at $1.3 \mathrm{~mm}$ concentration, and failed to cause significant inhibition of pyruvateferredoxin oxidoreductase activity (Table 3). At $6 \cdot 2 \mathrm{mM}-\left[\mathrm{Fe}_{4} \mathrm{~S}_{3}(\mathrm{NO})_{7}\right]$, hydrogenase activity was inhibited to a greater extent than pyruvate-ferredoxin oxidoreductase activity, but this concentration is much higher than that required to prevent cell growth. 


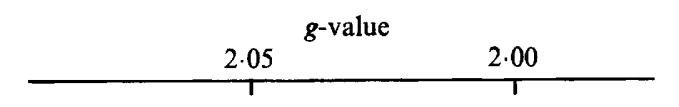

(a)
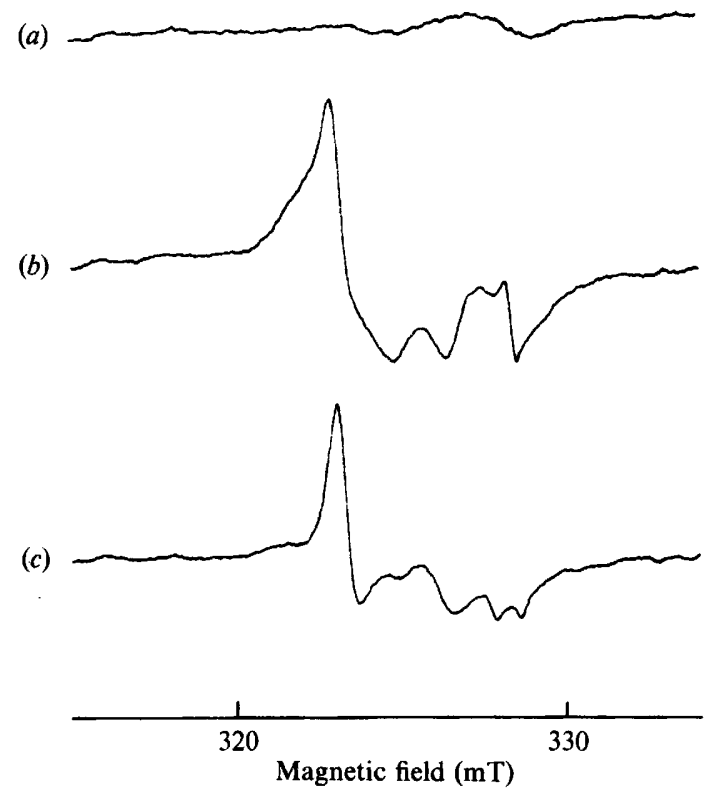

Fig. 4. EPR spectra at $90 \mathrm{~K}$ showing nitrosyl formation in cells after growth with $\mathrm{M} 1$ or $\mathrm{M} 2$. (a) Control culture $\left(96 \mathrm{mg}\right.$ protein $\left.\mathrm{ml}^{-1}\right)$. (b) Cells grown with $\mathrm{M} 1$ at a concentration of $56 \mathrm{ml} \mathrm{l}^{-1}(80 \mathrm{mg}$ protein $\left.\mathrm{ml}^{-1}\right)$. (c) Cells grown with M2 at a concentration of $56 \mathrm{ml} \mathrm{l}^{-1}(36 \mathrm{mg}$ protein $\mathrm{ml}^{-1}$ ). Conditions of measurement: microwave power $20 \mathrm{~mW}$, modulation amplitude $0.1 \mathrm{mT}$, microwave frequency $9.232 \mathrm{GHz}$, gain $\times 2000$.

\section{$E P R$ of cell interactions with $[\mathrm{Fe}-\mathrm{S}-\mathrm{NO}]$ species}

M1 was weakly paramagnetic, and produced an EPRdetectable iron-nitrosyl signal at $g=2.03$ (not shown). Double integration of the signal indicated that it corresponded to only $0.028 \mathrm{mM}$ spin concentration, i.e. $8 \%$ of nitrite added (assuming the signal indicates a dinitrosyl species). This signal disappeared on autoclaving. Thus both $\mathrm{M} 1$ and M2 were predominantly EPR-silent.

EPR spectra, recorded at $90 \mathrm{~K}$, of cells grown in the presence of M1 or M2 (Fig. 4) showed signals around $g=2 \cdot 04$. These were not seen in control cells, and are indicative of mononuclear iron-nitrosyl species of the type $\left[\mathrm{Fe}(\mathrm{NO})_{2}(\mathrm{SR})_{2}\right]^{-}$. The intensity of these signals in cells grown with M1 (Fig. $4 b$ ), which permitted normal cell growth, was similar to or greater than the intensity in cells grown with $\mathrm{M} 2$ (Fig. $4 c$ ), which totally inhibited cell growth. Similarly, EPR spectra at $90 \mathrm{~K}$ of cells after growth with higher dilutions of M2 showed iron-nitrosyl signals at $g=2 \cdot 04$, even when the concentrations added were too low to cause inhibition of cell growth.

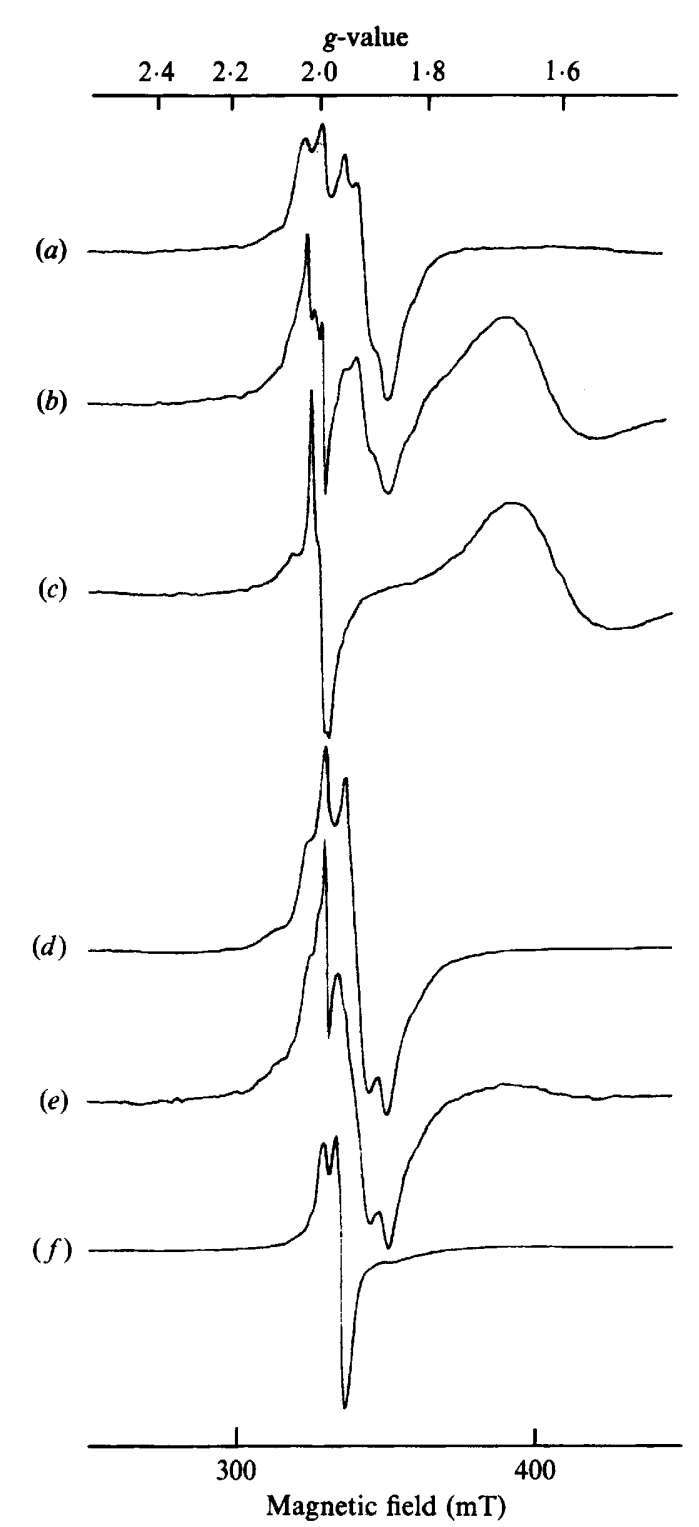

Fig. 5. EPR investigation of signals indicative of reduced iron-sulphur proteins in cells after inhibition by M1 or M2. (a) Control cells as prepared, gain $\times 250$. (b) Cells grown with $\mathrm{Ml}$ at a concentration of $56 \mathrm{ml} \mathrm{l}^{-1}$, as prepared, gain $\times 250$. (c) Cells grown with M2 at a concentration of $56 \mathrm{ml} \mathrm{l}^{-1}$, as prepared, gain $\times 250$. (d) As $(a)$, reduced by $2 \mathrm{~mm}$-dithionite, gain $\times 125$. (e) As (b), reduced by $2 \mathrm{~mm}-$ dithionite, gain $\times 250$. $(f)$ As $(c)$, reduced by 2 mM-dithionite, gain $\times 50$. Conditions of measurement: temperature $16 \mathrm{~K}$, microwave power $20 \mathrm{~mW}$, modulation amplitude $0.1 \mathrm{mT}$, microwave frequency $9 \cdot 188 \mathrm{GHz}$.

EPR spectra of cells, recorded at $16 \mathrm{~K}$, showed signals around $g=1.94$, due to reduced iron-sulphur clusters (Fig. 5a). This signal was decreased in cells grown with M1, and absent from cells grown with M2 (Fig. $5 b, c$ ). The effect of M1 could be explained by a partial oxidation of the iron-sulphur clusters, since the $g=1.94$ signal was restored by reduction with dithionite (Fig. 

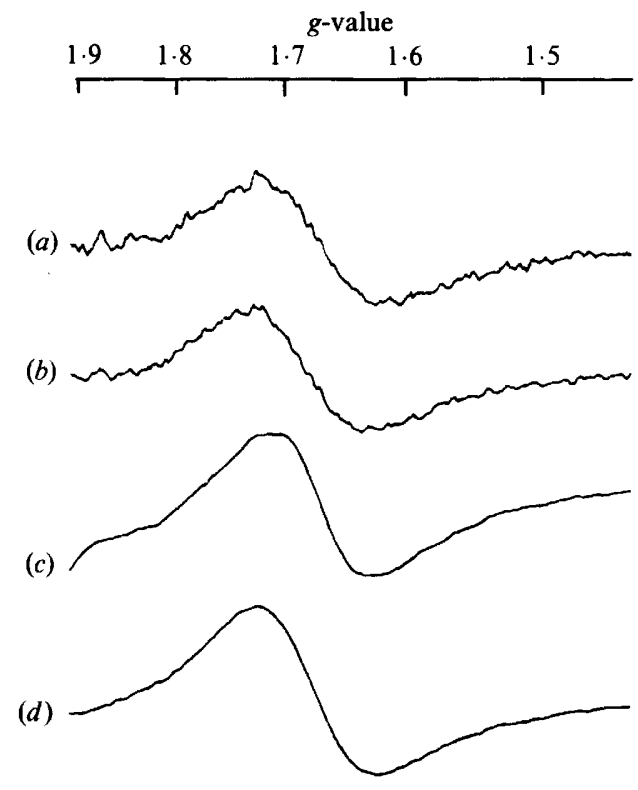

(e)

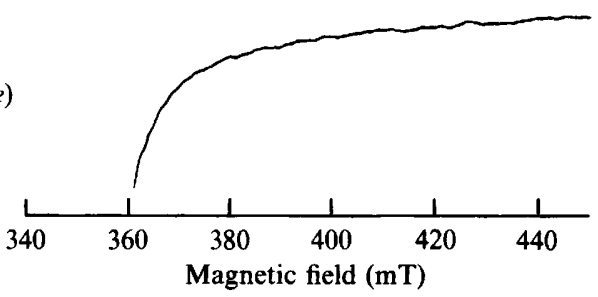

Fig. 6. EPR of cells after growth inhibition with $\left[\mathrm{Fe}_{4} \mathrm{~S}_{3}(\mathrm{NO})_{7}\right]$, $\left[\mathrm{Fe}_{4} \mathrm{~S}_{4}(\mathrm{NO})_{4}\right],\left[\mathrm{Fe}_{2}(\mathrm{SMe})_{2}(\mathrm{NO})_{4}\right]$, or M2. (a) Cells with M2 at $56 \mathrm{ml} \mathrm{l}^{-1}$ concentration. (b) Cells with $40 \mu \mathrm{M}-\left[\mathrm{Fe}_{4} \mathrm{~S}_{3}(\mathrm{NO})_{7}\right]$. (c) Cells with $40 \mu \mathrm{M}-$ $\left[\mathrm{Fe}_{4} \mathrm{~S}_{4}(\mathrm{NO})_{4}\right] .($ d $)$ Cells with $40 \mu \mathrm{M}-\left[\mathrm{Fe}_{2}(\mathrm{SMe})_{2}(\mathrm{NO})_{4}\right]$. (e) Control cells. Conditions of measurement: temperature $16 \mathrm{~K}$, microwave power $20 \mathrm{~mW}$, modulation amplitude $0.02 \mathrm{mT}$, microwave frequency $9 \cdot 1 \mathrm{GHz}$, gain $\times 2000$.

$5 e$ ). By contrast, dithionite did not restore the signal in cells grown with M2 (Fig. $5 f$ ), indicating that the ironsulphur clusters had disappeared. Incubation of reduced ferredoxin with M2 did not cause a decrease in the $g=1.94$ signal intensity (data not shown).

Growth with M1 or M2 also induced a broad EPR signal at a $g$-value around 1.65 (Fig. $4 b, c$ ). This spectrum was similar to those observed in cells grown with the inhibitory (and much higher) concentrations of nitrite plus ascorbate (Payne et al., 1990). The spectrum disappeared on addition of dithionite (Fig. $5 e, f$ ), indicating that it represents an oxidized species, or one destroyed by dithionite. The $g=1.65$ signal was not observed in samples of supernatant obtained after cell growth, and was dependent on the presence of cells.

EPR spectra at $16 \mathrm{~K}$ of the washed cell pellets after growth with several of the [Fe-S-NO] species, also showed broad signals at $g=1.65$ (Fig. 6). We have

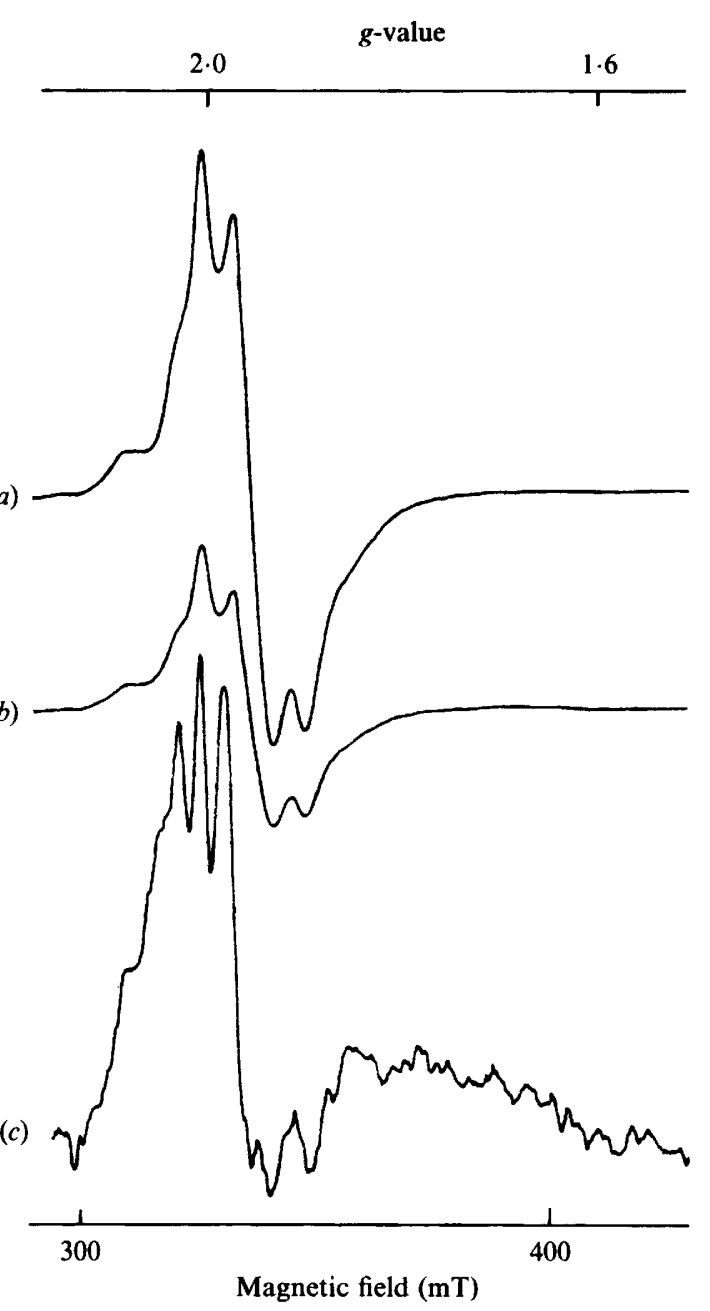

Fig. 7. EPR study of soluble cell extract after growth with M1 or M2. (a) Control cell extract, gain $\times 200\left(23 \mathrm{mg}\right.$ protein $\left.\mathrm{ml}^{-1}\right)$. (b) Extract from cells grown with $\mathrm{M} 1$, gain $\times 200\left(20 \mathrm{mg}\right.$ protein $\left.\mathrm{ml}^{-1}\right)$. (c) Extract from cells grown with $\mathrm{M} 2,\left(0.18 \mathrm{mg}\right.$ protein $\left.\mathrm{ml}^{-1}\right)$, gain $\times 2000$. Conditions of measurement: temperature $13 \mathrm{~K}$, microwave power $20 \mathrm{~mW}$, modulation amplitude $0.1 \mathrm{mT}$, microwave frequency $9 \cdot 187 \mathrm{GHz}$.

previously observed these signals in cells and soluble cell extracts (Payne et al., 1990) incubated with nitrite and ascorbate at concentrations inhibitory to cell growth. So far, the occurrence of these signals has coincided with cell damage and pigmentation. Iron-nitrosyl signals at $g=2.03$ (measured at $90 \mathrm{~K}$ ) were also detected, but as in our previous studies (Payne et al., 1990), the signal intensity after cell growth with [Fe-S-NO] complexes did not correspond to the degree of growth inhibition.

EPR spectroscopy of soluble extracts prepared from cells grown in the presence of $\mathrm{M} 1$ or $\mathrm{M} 2$, and reduced with $2 \mathrm{mM}$ dithionite, revealed signals at around $14 \mathrm{~K}$, typical of reduced clostridial ferredoxins (Fig. 7). The signal size from extract obtained after cell growth with M1 (Fig. 7b) was about half that of control cells (Fig. 7a), 

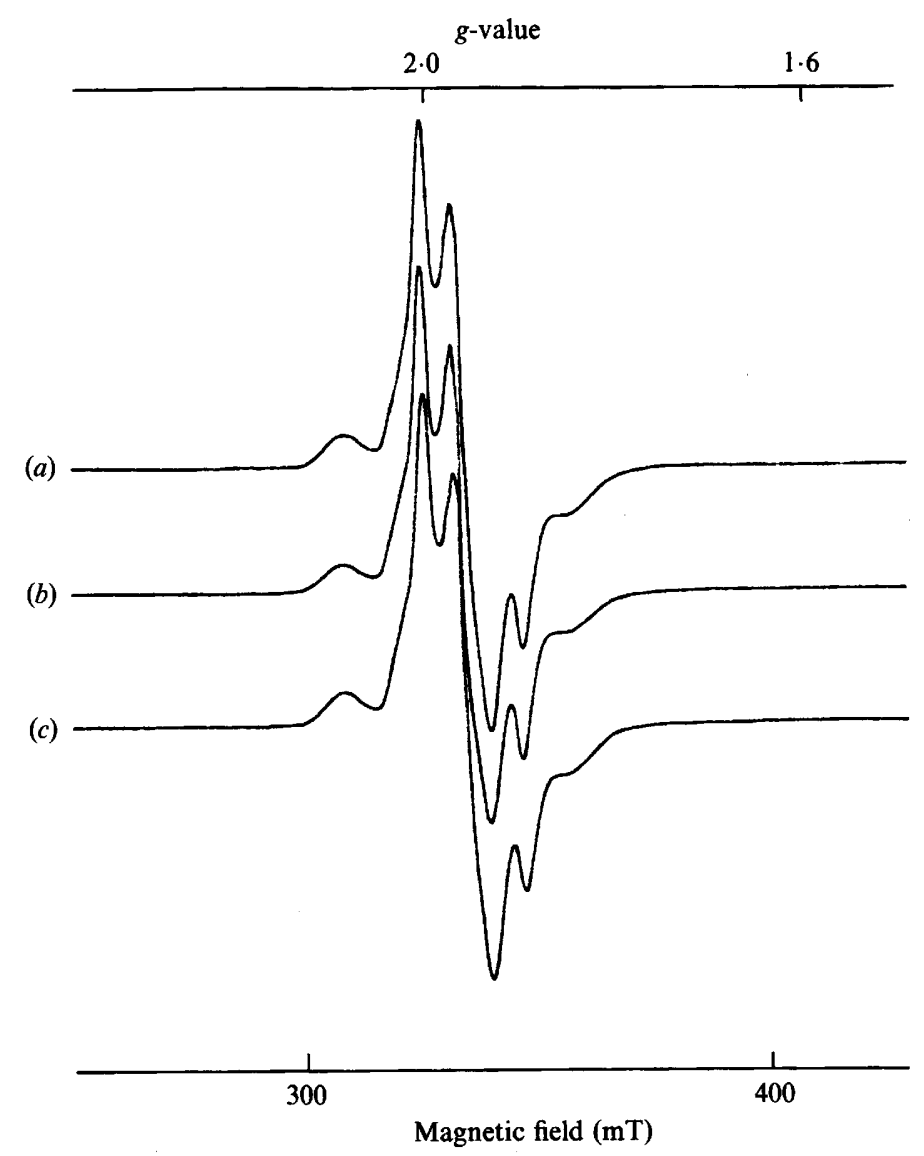

Fig. 8. EPR of purified ferredoxin after incubation with M1 or M2. (a) Ferredoxin as prepared. (b) After incubation with $\mathrm{Ml}$ at $56 \mathrm{ml} \mathrm{l}^{-1}$ concentration, for $1 \mathrm{~h}$ at room temperature. (c) After incubation with $\mathrm{M} 2$ at $56 \mathrm{ml} \mathrm{l}^{-1}$ concentration, for $1 \mathrm{~h}$ at room temperature. Conditions of measurement: temperature $13.4 \mathrm{~K}$, microwave power $20 \mathrm{~mW}$, modulation amplitude $0 \cdot 1 \mathrm{mT}$, microwave frequency $9 \cdot 188 \mathrm{GHz}$, gain $\times 250$.

but the cell yield (in 1 $^{-1}$ ) after growth with M1 (Payne et al. 1990) was $98 \%$ of the control cells. The spectrum of extracts from cells grown with M2 still showed evidence of reduced iron-sulphur centres, but was much smaller. This is expected, because cell growth was totally inhibited, and the cells appeared to have undergone disruption; the protein content of the extract was extremely low. In summary, the cells could continue to grow, although the amount of iron-sulphur clusters (mostly ferredoxin) was decreased; on the other hand, some iron-sulphur clusters remained even under conditions of complete growth inhibition.

The effects of the [Fe-S-NO] complexes on ferredoxin were tested by observing its EPR spectrum. The normal EPR spectrum of reduced ferredoxin is shown in Fig. $8 a$ ). This spectrum was virtually unaffected by incubation for $1 \mathrm{~h}$ with $\mathrm{M} 1$ or $\mathrm{M} 2$, at $56 \mathrm{ml} \mathrm{l}^{-1}$ concentration (Fig. $8 b, c$ ). The effects of the complexes on the ironsulphur proteins in the cell were also studied by EPR.

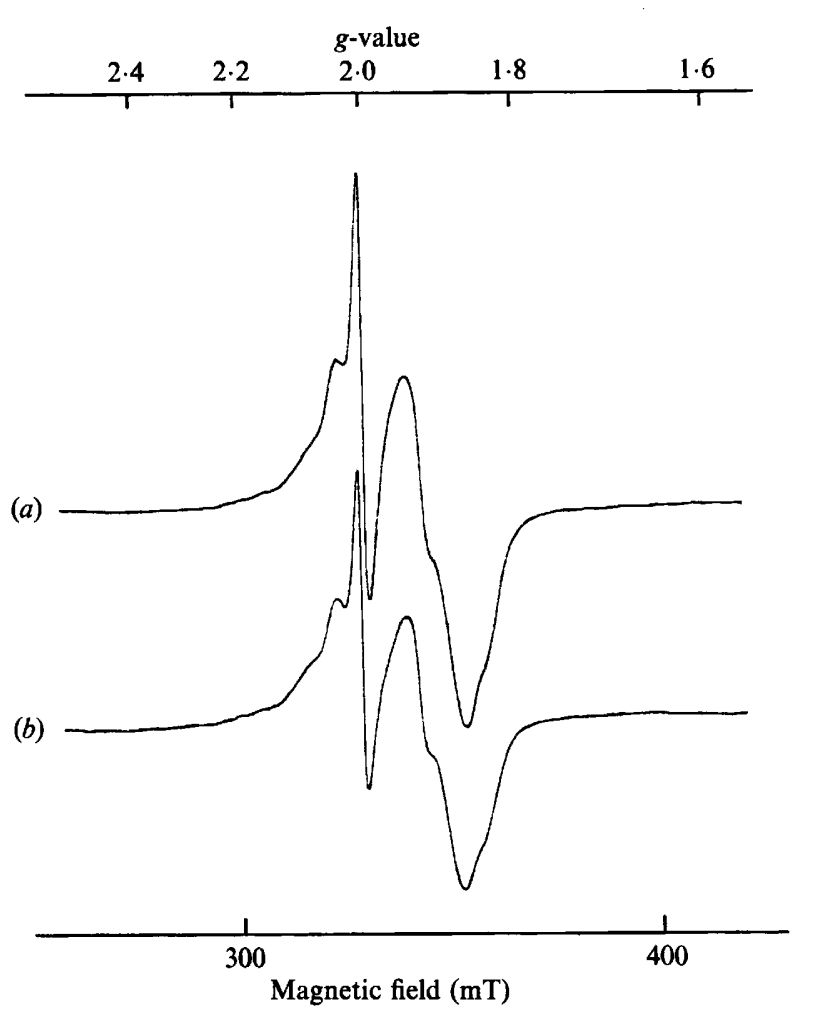

Fig. 9. EPR of extract devoid of ferredoxin after incubation with $\left[\mathrm{Fe}_{4} \mathrm{~S}_{3}(\mathrm{NO})_{7}\right]$. (a) Extract as prepared. (b) Extract with $0.413 \mathrm{~mm}$ $\left[\mathrm{Fe}_{4} \mathrm{~S}_{3}(\mathrm{NO})_{7}\right]$, after incubation at room temperature for $15 \mathrm{~min}$. Conditions of measurement: temperature $15 \mathrm{~K}$, microwave power $20 \mathrm{~mW}$, modulation amplitude $0.1 \mathrm{mT}$, microwave frequency $9 \cdot 192 \mathrm{GHz}$, gain $\times 200$.

Spectra of cell extracts from which ferredoxin had been removed show the presence of other reduced $[4 \mathrm{Fe}-4 \mathrm{~S}]$ clusters (Fig. 9a), which are found in various proteins, including hydrogenase and pyruvate-ferredoxin oxidoreductase. After incubation of this extract with $0.413 \mathrm{mM}-\left[\mathrm{Fe}_{4} \mathrm{~S}_{3}(\mathrm{NO})_{7}\right]$ for $15 \mathrm{~min}$ at room temperature (Fig. $9 b$ ), the spectrum was partly decreased but the shape remained the same, indicating that the principal [4Fe-4S] clusters were not drastically affected by bacteriostatic concentrations of this compound.

\section{Discussion}

In heated cured meats, around $50 \mathrm{mg}$ of $\mathrm{NaNO}_{2}$ $(\mathrm{kg} \text { meat })^{-1}$ is involved in interactions with haem and non-haem iron (van Roon, 1980). This nitrite level is roughly equivalent to $725 \mu \mathrm{M}$ concentration, and is an order of magnitude higher than that found necessary to form the potent growth inhibitor(s) that we formed in the presence of $\mathrm{FeSO}_{4}$ and cysteine. In meat, much of the nitrite (as nitric oxide) is likely to be sequestered in 
less inhibitory forms such as nitrosyl haems (formed from interaction with porphyrins, etc.).

Perigo \& Roberts (1968) originally observed the 'Perigo effect' (enhanced inhibition of clostridial growth after autoclaving nitrite in growth medium) at $\mathrm{pH} 6.0$ and above. In the present work, we observed total inhibition of clostridial growth at $\mathrm{pH} 7.4$ by $40 \mu \mathrm{M}$ $\mathrm{NaNO}_{2}$, in the form of [Fe-S-NO] complexes, while $40 \mu \mathrm{M}-\mathrm{NaNO}_{2}$ alone, when autoclaved in medium, failed to inhibit growth. Therefore, the inhibitor formed in this study appears to be more potent than, and different from, the 'Perigo factor'. Cell growth was not inhibited when the concentration of $\mathrm{FeSO}_{4}$ was limiting in autoclaved mixtures of cysteine and nitrite, so it can be concluded that if cysteine-nitrosothiols form, they are not responsible for cell growth inhibition. It is unlikely that the neutral/basic environment of growth medium ( $\mathrm{pH} 7.4)$ would facilitate nitrosothiol formation, which occurs between nitrite and cysteine at pH 2 (Moran et al., 1975). It therefore appears that the inhibitory species formed are not 'Perigo inhibitors' or nitrosothiols.

We have found (cf. Payne et al., 1990) that the cell lysis, pigmentation and visual damage of cells (observed by electron microscopy) induced by nitrite is enhanced if the nitrite is in the form of [Fe-S-NO] complexes. It is possible that complex formation from nitrite may maximize the availability of nitric oxide within a given system. When these [Fe-S-NO] complexes decompose, they evolve nitric oxide. This method of producing nitric oxide may be more efficient than that of nitrite reduction by ascorbate.

Cassens et al. (1979) found that addition of around $100 \mu \mathrm{M}-\mathrm{Fe}$ (II) to meat emulsions resulted in a higher level of protein-bound nitrite. This concentration of iron is comparable to the levels which were inhibitory in the present study. The [Fe-S-NO] inhibitors formed in our studies were produced at moderate $\mathrm{pH}$, and required heat. Thermal processing of meats may result in similar reactions. Under usual cured meat conditions, the molar ratio of $\mathrm{NaNO}_{2}$ added to reduced thiol groups is around $1: 9$ (Cassens et al., 1979), providing an excess of reduced thiol groups over those necessary (in the form of cysteine) for cell growth inhibition. In addition, the detectable range of free iron in muscle meats such as turkey and chicken (Kanner et al., 1988) correlates well with the millimolar levels of $\mathrm{FeSO}_{4}$ found necessary to inhibit growth in this study. Therefore iron, nitrite and thiols appear to be present in meat at suitable concentrations for [ $\mathrm{Fe}-\mathrm{S}-\mathrm{NO}]$ formation.

Butler et al. (1988) have suggested that, of the [Fe-S-NO] compounds known, $\left[\mathrm{Fe}(\mathrm{NO})_{2}(\mathrm{SR})_{2}\right]$ could be the major antimicrobial species involved. This paramagnetic species is easily detected using EPR. However, the EPR spectra obtained in experiments in the present work showed $g=2.03$ signals when cell growth was not inhibited, and weak signals when cell growth was completely stopped. This lack of correlation indicates that the most potent antimicrobial agents are EPRsilent species. M2, and most of the [Fe-S-NO] complexes except $\left[\mathrm{Fe}(\mathrm{NO})_{2}(\mathrm{SR})_{2}\right]$, prior to interaction with the cells, are EPR-silent, which eliminates mono-iron-nitrosyl species such as $\left[\mathrm{FeNO}(\mathrm{SR})_{3}\right]$, $\left[\mathrm{Fe}(\mathrm{NO})_{2}(\mathrm{SR})_{2}\right]$ and $\left[\mathrm{Fe}(\mathrm{NO})_{3}(\mathrm{SR})\right]$ as the primary inhibitors. [ $\mathrm{Fe}($ cysteine $\left.)(\mathrm{NO})_{2}\right]$ is diamagnetic, and may form an EPR-silent species in the autoclaved preparations of $\mathrm{NaNO}_{2}, \mathrm{FeSO}_{4}$ and cysteine. However, excess nitric oxide appears to be necessary for its formation (Larkworthy et al., 1977), making it a less likely candidate. $\left[\mathrm{Fe}(\mathrm{NO})_{2}(\mathrm{SPh})_{2}\right]$ was non-inhibitory at $10 \mu \mathrm{M}$ concentration but higher concentrations were not possible because of insolubility following addition to the growth medium.

High-spin ferrous-nitrosyls (with $g$-values at 2.0 and 4.0 ), were formed when $M 1$ was autoclaved to yield $M 2$, prior to adding to growth medium. We have observed these signals in medium after cell growth inhibition by concentrations of nitrite (and equimolar ascorbate) above $10 \mathrm{mM}$. High-spin ferrous-nitrosyl compounds are readily formed by iron and nitrite with EDTA (Bonner $e t$ al., 1978; Rich et al., 1978). Tompkin et al. (1978) found that EDTA acted synergistically with nitrite to inhibit cell growth, though they concluded that its action was to sequester cations essential for botulinal outgrowth. Vanin \& Aliev (1983) found that ascorbate anions reacted with $\mathrm{Fe}^{2+}$ ions, forming both low-spin and highspin ferrous-nitrosyl complexes, the former characterized by $g=2.02-2.04$ and the latter by $g=4.0$ and 2.0 . They failed to find any ligands present in animal tissues which could form high-spin nitrosyl complexes with iron. Our studies did not involve EDTA, and ascorbate was not necessary in the formation of high-spin ferrousnitrosyls. However, because high levels of nitrite are needed for EPR-detectable high-spin nitrosyl formation, and for total inhibition of cell growth, we have not found any correlation between these signals and the antimicrobial activity of nitrite in foods.

The broad EPR signals around $g=1.65$ detected after cell growth with either M1 or M2 are interesting. No information about this signal appears to have been published before, possibly because most EPR spectroscopic studies of nitrosyl formation have been carried out at temperatures above $100 \mathrm{~K}$. Because the signal was also observed after treating cells grown under normal conditions with nitrite and ascorbate, there may be a link between the mode of action of nitrite and of [Fe-S-NO] species. The tendency of this signal to form in the presence of lower concentrations of $\mathrm{NaNO}_{2}$, when used with $\mathrm{FeSO}_{4}$ and cysteine, matches the tendency of 
$\mathrm{NaNO}_{2}$ to inhibit cell growth under similar conditions. Although the signal was sometimes absent when cell growth was totally inhibited, this may have been due to the reduced state of the cells, as the signal disappeared on treatment with strong reducing agents, e.g. dithionite. We have also observed this signal after heating M1 (at $0.056 \mathrm{ml} \mathrm{ml}^{-1}$ concentration, where nitrite $=0.04 \mathrm{mM}$ ) with cell-free extract of $C$. sporogenes, at $60^{\circ} \mathrm{C}$ for $5 \mathrm{~min}$. This indicates that the species may form because of a direct interaction of $[\mathrm{Fe}-\mathrm{S}-\mathrm{NO}]$ species with cytosolic proteins.

All of the compounds tested, and the mixtures of iron, nitrite and cysteine, were bacteriostatic, but some required significantly higher concentrations than others. Our benchmark for the bacteriostatic species is a compound present in the autoclaved mixture M2. This is relatively stable and water-soluble, and acts at an effective nitrite concentration of $40 \mu \mathrm{M}$ or less. The minimum inhibitory concentration of $\left[\mathrm{Fe}_{2}(\mathrm{SMe})_{2}(\mathrm{NO})_{4}\right]$ required was considerably higher than this (Table 2). The most potent bacteriostatic [ $\mathrm{Fe}-\mathrm{S}-\mathrm{NO}]$ complexes of known formula that we have used are the EPRsilent complexes $\left[\mathrm{Fe}_{4} \mathrm{~S}_{3}(\mathrm{NO})_{7}\right]$ and $\left[\mathrm{Fe}_{4} \mathrm{~S}_{4}(\mathrm{NO})_{4}\right]$. $\left[\mathrm{Fe}_{4} \mathrm{~S}_{3}(\mathrm{NO})_{7}\right]$ was as effective as $\mathrm{M} 2$ on the basis of nitrite equivalents, while $\left[\mathrm{Fe}_{4} \mathrm{Se}_{3}(\mathrm{NO})_{7}\right]$ was somewhat less effective. However, these comparisons cannot be precise, since the compounds can interconvert in the complex aqueous growth medium. Some of the $[\mathrm{Fe}-\mathrm{S}-\mathrm{NO}]$ complexes were poorly soluble in the water ethanol mixtures in which they were added. It is possible, therefore, that the concentration of the actual inhibitory species in solution may be lower than the total concentration of the compound added. Since cells grown on each of the complexes yielded a similar $g=1.65 \mathrm{EPR}$ signal, it is possible that it is the interaction with cells which produces a similar inhibitory product.

The interactions of nitrite and nitric oxide with ironsulphur clusters to form [ $\mathrm{Fe}-\mathrm{S}-\mathrm{NO}$ ] compounds, and their subsequent interconversions (Butler et al., 1988) might be significant for two reasons.

1. The destruction of iron-sulphur clusters in proteins by nitrite or nitrosyl complexes could form a basis for the inhibition of metabolism and hence of cell growth. The results presented here and in the accompanying paper (Payne et al., 1990) indicate that although nitrite or [Fe-S-NO] complexes have relatively little effect on the levels of iron-sulphur proteins in vitro, they can cause a definite decrease in the same enzymes in vivo. One possible explanation for this decrease is that the complexes could inhibit the assembly of iron-sulphur clusters into proteins. The mechanisms for biosynthesis of iron-sulphur proteins are at present unknown. As discussed previously (Payne et al., 1990), the decrease in the levels of iron-sulphur proteins may contribute to the loss of viabilty of the cells, but is probably not the principal cause.

2. The interaction of nitrite and nitric oxide with iron-sulphur proteins, or with precursor iron-sulphur clusters, could provide a mechanism for the formation of [Fe-S-NO] compounds which could then inhibit the cells in other ways. Pigmentation of cells by these [ $\mathrm{Fe}-\mathrm{S}-\mathrm{NO}]$ complexes, and lack of EPR-detectable nitrosyl formation in the medium, indicate that the complexes have an affinity for the cells. This may perhaps be due to their hydrophobic nature.

We thank R. Lambert (St Andrews), who provided some of the [Fe-S-NO] salts. This work was supported by a postgraduate award from the Ministry of Agriculture, Fisheries and Food to M. J.P., and in part by grants from the Agricultural and Food Research Council and the Science and Engineering Research Council.

\section{References}

ASAN, T. \& SolBerg, M. (1976). Inhibition of $\mathrm{Cl}$. perfringens by heated combinations of nitrite, sulfur and ferrous or ferric ions. Applied and Environmental Microbiology 31, 49-52.

Baty, J. D., WILlis, R. G., BuRden, M. G., Butler, A. R., GLIDEWELL, C., JoHnson, I. L. \& MASSEY, R. (1987). Formation of bis( $\mu$-methanethiolato)bis(dinitrosyl-iron) from parsley ferredoxins and nitrite. Inorganica Chimica Acta 138, 15-16.

BonNer, W. D., JR, Blum, H., Rich, P. R. \& SAlerno, J. C. (1978). Further observation on a mitochondrial metallocompound and on a ferrous-EDTA-NO model compound. In Frontiers of Biological Energetics, pp. 997-1001. London: Academic Press.

Butler, A. R., Glidewell, C., Hyde, A. R., McGinnis, J. \& SEYMOUR, J. E. (1983). Ligand exchange processes in some ironsulphur-carbonyl and -nitrosyl complexes. Polyhedron 2, 1045-1052.

Butler, A. R., Glidewell, C., Hyde, A. R. \& Walton, J. C. (1985a). Nitrosylation of $[2 \mathrm{Fe}-2 \mathrm{~S}]$ and [4Fe-4S] models for iron-sulphur redox proteins. Inorganica Chimica Acta 106, L7-L8.

Butler, A. R., GlideWell, C., HỴDE, A. R. \& Walton, J. C. (1985b). Formation of paramagnetic mononuclear iron-nitrosyl complexes from diamagnetic di- and tetra-nuclear iron-sulphur nitrosyl; characterisation by EPR spectroscopy and study of thiolate and nitrosyl ligand exchange reactions. Polyhedron 4, 797-809.

Butler, A. R., GLidEWell, C. \& LI, M.-H. (1988). Nitrosyl complexes of iron-sulphur clusters. In Advances in Inorganic Chemistry, pp. 335-393. Edited by A. G. Sykes. London: Academic Press.

Cassens, R. G., Greaser, M. L., Ito, T. \& LeE, M. (1979). Reactions of nitrite in meat. Food Technology July, 45-46.

DoYLE, M. P., VAN DoORnIK, F. J. \& FUnCKes, C. L. (1980). Nitrosyl transfer to metalloproteins. Selective intermolecular transfer of the nitrosyl group from cobalt nitrosyls to hemoglobin and myoglobin. Inorganica Chimica Acta 46, L111-L113.

Field, L., Dilts, R. V., Ravichandran, R., Lenhert, P. G. \& CaRnahan, G. E. (1978). An unusually stable thionitrite from $N$-acetyl-DL-penicillamine; X-ray crystal and molecular structure of 2-(acetylamino)-2-carboxy-1,1-dimethylethyl thionitrite. Journal of the Chemical Society: Chemical Communications 249-250.

HuHTANEN, C. N. \& Wasserman, A. E. (1975). Effect of added iron on the formation of clostridial inhibitors. Applied Microbiology 30, 768-770.

INCZE, K., FARKAS, J, MiHAYALI, V. \& ZUKAL, E. (1974). Antibacterial effect of cysteine nitrosothiol and possible precursors thereof. Applied Microbiology 27, 202-205.

KANNER, J., HAZAN, B. \& Doll, L. (1988). Catalytic free iron ions in muscle foods. Journal of Agricultural and Food Chemistry 36, 412-414. 
Larkworthy, L. F., Turnbull, M. H. \& Yavari, A. (1977). Possible role of iron II amino acid complexes in nitrite depletion and inhibitor formation in cured meats. Chemistry and Industry, May 21st, 401-402.

Moran, D. M., TANNenbaum, S. R. \& ARCheR, M. C. (1975). Inhibitor of $\mathrm{Cl}$. perfringens by heating sodium nitrite in a chemically defined medium. Applied Microbiology 30, 838-843.

Payne, M. J., Woods, L. F. J., Gibes, P. \& Cammack, R. (1990). Electron paramagnetic resonance spectroscopic investigation of the inhibition of the phosphoroclastic system of Clostridium sporogenes by nitrite. Journal of General Microbiology 136, 2067-2077.

Perigo, J. A. \& RoberTs, T. A. (1968). Inhibition of clostridia by nitrite. Journal of Food Technology 3, 91-94.

Perigo, J. A., Whiting, E. \& Bashrord, T. E. (1967). Observations on the inhibition of vegetative cells of $\mathrm{Cl}$. perfringens by nitrite which has been autoclaved in a laboratory medium, discussed in the context of sub-lethally processed cured meats. Journal of Food Technology 2 , 377-397.

Reddy, D., Lancaster, J. R., JR \& CORNForTh, D. P. (1983). Nitrite inhibition of $\mathrm{Cl}$. botulinum; electron spin resonance detection of ironnitric oxide complexes. Science 221, 769-770.

Rich, P. R., Salerno, J. C., Leigh, J. S. \& BonNer, W. D., JR (1978). A spin $3 / 2$ ferrous-NO derivative of an iron containing moiety associated with Neurospora crassa and higher plant mitochondria. FEBS Letters 93, 323-326.

RiHA, W. E. \& SOLBERG, M. (1975). Cl. perfringens growth in nitrite containing medium sterilised by heat or filtration. Journal of Food Science 40, 443-445.

VAN ROON, P. S. (1974). Inhibitors in cooked meat products. Proceedings of the Ist International Symposium on Nitrite in Meat Products, Zeist, The Netherlands, p. 117.

VAN ROON, P. S. (1980). Clostridium botulinum inhibition in cured meats by nitrite and by heat treatment. Antonie van Leeuwenhoek 46, 515-516.

Roussin, M. L. (1858). Recherches sur les nitrosulfures doubles de fer. Annals Chimie et de Physique 52, 285-301.

Strasdeit, H., KREBS, B. \& HeNKeL, G. (1986). Structure and synthesis of $\left[\mathrm{Fe}(\mathrm{SPh})_{2}(\mathrm{NO})_{2}\right]^{-}$, the 'monomer' of Roussin's phenyl ester. Zeitschrift für Naturforschung 41B, 1357-1362.

Tompkin, R. B., Christiansen, L. N. \& Shaparis, A. B. (1978). Antibotulinal role of isoascorbate in cured meats. Journal of Food Science 43, 1368-1370.

VANIN, A. F. \& ALIEv, D. I. (1983). High-spin nitrosyl non-heme iron complexes in animal tissues. Studia Biophysica 93, 63-68. 